\title{
Ploidy of Bacillus subtilis exfusants: the haploid nature of cells forming colonies with biparental or prototrophic phenotypes
}

\author{
Philippe M. Hauser and Dimitri Karamata*: \\ Institut de génétique et biologie microbiennes, Rue César-Roux 19, 1005 Lausanne, Switzerland
}

(Received 30 October 1991; revised 14 January 1992; accepted 21 February 1992)

\begin{abstract}
To investigate the relationship between DNA content and cell volume, we have attempted to repeat the construction of stable Bacillus subtilis diploid cells through protoplast fusion. Colonies with a biparental phenotype and those with a prototrophic phenotype were identified among exfusants of a cross between two polyauxotrophic strains. The ploidy of cells constituting such colonies was assessed by protoplast self-fusion, determination of the DNA to dry weight ratio of exponentially growing cells, and by quantitative DNA-DNA hybridization. Within the precision of these methods, all colonies were found to consist of haploid cells. A previously described noncomplementing diploid was also found to be haploid. Therefore, the genetic evidence in favour of diploidy, based on continuing segregation of cells with a parental or recombinant phenotype, cannot be accounted for except by the maintenance of such cells as a minority population in mixed colonies through cross-feeding. Reconstruction experiments with mixtures of whole parental cells confirm that biparental colonies are indeed mixed colonies which arise either by sticking of parental cells or through coincidence, i.e. their plating within a distance of about $0.4 \mathrm{~mm}$. The previously reported experimental results can be accounted for in the light of our results.
\end{abstract}

\section{Introduction}

One of the fundamental distinctive characteristics of the prokaryotic cell is its permanently haploid state. The presence of two genomes in spores of some spore-forming bacilli such as Bacillus megaterium or Bacillus cereus is not paralleled by permanent diploidy during exponential growth. The quantity of DNA per cell varies during the cell cycle and it has been suggested that initiation of chromosome replication is related to cell mass (Donachie, 1968). Dichotomous chromosome replication also results in a variable quantity of DNA per cell amounting, in rich medium, to nearly four genome equivalents of DNA (Bremer \& Dennis, 1987). However, shorter generation times are accompanied by increased cell lengths (Schlaeppi et al., 1982). Thus, it is possible that the quantity of DNA which a growing cell can accommodate is somehow related to its volume or, in broader terms, to cell geometry.

In Bacillus subtilis, the quantity of DNA per cell has been altered by amplification of integrated plasmid DNA, as well as by generation of merodiploids. In the

\footnotetext{
* Author for correspondence. Tel. +41 21206075 ; fax +41 21 206078.

Abbreviations: CD, complementing diploid; NCD, non-complementing diploid; ND, nephelometric density.
}

former case, a global increase of DNA per cell of up to $10 \%$ has generally been observed (see Young \& Hranueli, 1988 for a review), whereas in merodiploid strains, a diploid region encompassing up to $25 \%$ of the chromosome has been described (Schneider et al., 1982). Recent studies report amplified DNA equivalent to 55 or even $75 \%$ of the genome (Petit et al., 1990; Ives \& Bott, 1990). However, although in the latter case a decrease in cell growth rate was reported, no thorough physiological studies, in particular a measurement of the cell size, were performed.

A system ideally suited for investigating the influence of the DNA content on cell volume was reported in $B$. subtilis, where permanently diploid cells were identified. The latter were either complementing diploids (CD) (Lévi, 1978; Lévi-Meyrueis et al., 1980), partially complementing diploids (Sanchez-Rivas et al., 1982), or non-complementing diploids (NCD) (Hotchkiss \& Gabor, 1980). In the latter case, one of the chromosomes is expressed (the 'speaking' chromosome), whereas the other is not ('silent').

Since the isolation and subsequent characterization of the diploids was the aim of the present study, a brief schematic description of the method used for their production and identification is provided (see Fig. 1). Cultures of two genetically labelled parent strains, 
generally complementary multiple auxotrophs, are converted into protoplasts by lysozyme treatment, fused by addition of polyethylene glycol (PEG) and plated for single colonies on a rich regeneration medium on which cell wall synthesis can proceed (Schaeffer et al., 1976). Exfusants are transferred, by toothpicks, onto three solid minimal media: minimal medium alone, that containing the growth requirements of parent 1 and that containing those of parent 2. Growth on both supplemented media but not on minimal medium defines a biparental colony that contains NCD cells (Hotchkiss \& Gabor, 1980). It is assumed that in the latter cells one of the parent chromosomes is expressed, while the other is silenced. Therefore, such cells cannot grow on minimal medium. In later contributions presence of NCD cells in biparental colonies was assessed by the segregation of recombinants upon subcloning in DNAase-containing liquid media (Gabor \& Hotchkiss, 1982, 1983). Absence of growth on all three media reveals a recombinant, possibly partially complementing diploid. Growth on all media defines either a prototrophic haploid recombinant or a CD. CDs differ from haploid recombinants (i) by their capacity to permanently segregate cells with parental and recombinant phenotypes (Lévi-Meyrueis $e t$ al., 1980; Sanchez-Rivas, 1982), and (ii) by being endowed with transforming activity for the auxotrophic alleles of both of their parents (Lévi, 1978; LéviMeyrueis et al., 1980). The identity of the silent chromosome in a NCD is revealed by a subsequent toothpick transfer onto an identical three-plate set (Fig. 1; Guillén et al., 1985). To avoid the possible loss of generally unstable NCD cells, present in the original biparental colony, transfers were always carried out with a toothpick. However, when stable clones were required, in particular those of the NCD type (Guillén et al., 1985), biparental colonies were resuspended and cultivated in a selection medium, the aim being to select during a long period, up to 50 generations, a given genotype, that of the speaking chromosome. The presence of the silent genome was subsequently assessed by its reactivation through protoplast self-fusion (Guillén et al., 1985) or by hybridization with a radioactive probe that has a homologous counterpart in the silent genome only (Guillén et al., 1985).

We report here the characterization of a series of exfusants with either the NCD or the CD phenotype, obtained by the method described above, as well as that of a NCD strain previously described (Lopez et al., 1986). The exfusants were all found to be formed of haploid cells. Reconstruction experiments with mixed populations of whole cells revealed that mixed colonies obey the operational definition of either NCDs or CDs, strongly suggesting that the exfusants examined here also consist of mixed populations of haploid cells.

This work was submitted by P. M. Hauser in partial fulfilment for a PhD degree of the University of Lausanne.

\section{Methods}

Bacterial strains and plasmids. These are listed in Table 1.

Biochemicals. [2-14 C]Thymidine $\left(51.4 \mathrm{mCi}^{\mathrm{mmol}}{ }^{-1} ; 1.9 \mathrm{GBq}\right.$ $\left.\mathrm{mmol}^{-1}\right)$ and $5^{\prime}-\left[\alpha^{-32} \mathrm{P}\right]$ deoxyadenosine triphosphate $\left(3000 \mathrm{Ci} \mathrm{mmol}^{-1}\right.$; $111 \mathrm{TBq} \mathrm{mmol}^{-1}$ ) were from Amersham, BSA fraction $\mathrm{V}$ and PEG 6000 were from Merck, DNAase I from BDH Chemicals or Fluka, and 2'-deoxyadenosine from Sigma.

Media. Rich medium L and minimal media S and TS were described by Karamata \& Gross (1970). L medium was supplemented with $20 \mu \mathrm{g}$ thymidine $\mathrm{ml}^{-1}$. NB is the complex medium of Schaeffer et al. (1965). $\mathrm{RD}$ is the cell wall regeneration medium of Wyrick \& Rogers (1973)

Table 1. Bacillus subtilis strains, and plasmids

\begin{tabular}{|c|c|c|}
\hline Strain & Genotype or description & Reference and remarks \\
\hline 168 & $\operatorname{trpC2}$ & Burkholder \& Giles (1947) \\
\hline M22 & purA16 leuA8 metB5 ilvAI & Karamata \& Gross (1970) \\
\hline S1 $1 \Delta 1$ & metB5 leuA8 thrB5 rfm-486 $\triangle$ ilvA $\mathrm{Cm}^{\mathrm{R} *}$ & Lopez et al. (1986) \\
\hline $\mathbf{S} 15(\mathrm{~S} 1 \Delta 1)$ & $\begin{array}{l}\text { purB34 ura-1 trpC7 rfm-486 (metB5 leuA8 thrB5 rfm-486 } \\
\text { AilvA } \mathrm{Cm}^{\mathrm{R}} \text { ) }\end{array}$ & $\begin{array}{l}\text { Lopez et al. (1986); stable NCD strain; indications in parentheses } \\
\text { refer to the silent chromosome }\end{array}$ \\
\hline $\begin{array}{l}\text { Plasmids } \\
\text { pHV32 } \\
\text { pphe }^{+1}\end{array}$ & & \\
\hline
\end{tabular}

* Plasmid pHV438 was obtained by insertion of two non-contiguous fragments flanking the ilvA gene into plasmid pHV32 (Niaudet et al., 1982). After linearization, the former plasmid has been integrated in the homologous chromosome region by two crossing-overs generating a deletion of the ilvA gene and conferring plasmid $\mathrm{Cm}$ resistance, to generate strain $\mathrm{S} 1 \Delta 1$. This type of construction provides genetically stable strains which segregate fewer than $1 \%$ of $\mathrm{Cm}^{\mathrm{s}}$ cells per 20 generations (Niaudet et al., 1985). 
supplemented with $5 \mu \mathrm{g}$ DNAase $\mathrm{I} \mathrm{ml}^{-1}$ (Schaeffer et al., 1976). $\mathrm{mR2}$ is the minimal cell wall regeneration medium of Sanchez-Rivas (1982). SMMD is the protoplasting medium of Wyrick \& Rogers (1973) supplemented with $5 \mu \mathrm{g}$ DNAase $\mathrm{I} \mathrm{ml}^{-1}$ (Schaeffer et al., 1976). SMMAD is SMMD supplemented with $1 \%(w / v)$ BSA (Gabor \& Hotchkiss, 1979). Solid media contained $1.2 \%(w / v)$ agar (Gibco). Solid NB medium was used for strain conservation after sporulation at $30^{\circ} \mathrm{C}$. When required, media were supplemented with amino acids $(20 \mu \mathrm{g}$ $\left.\mathrm{ml}^{-1}\right)$ and bases $\left(50 \mu \mathrm{g} \mathrm{ml}^{-1}\right)$.

Growth conditions. Unless otherwise stated, cultures were aerated by bubbling. Growth was followed by nephelometric density (ND) measured on a Unigalvo (Corning-EEL) nephelometer. In $\mathrm{L}$ medium, a ND reading of 100 corresponds to $1.5 \times 10^{8}$ c.f.u. $\mathrm{ml}^{-1}$.

Protoplast fusion. Fusions were performed essentially according to Gabor \& Hotchkiss (1979). However, bubbled rather than shaken cultures were grown in L instead of NB medium. Overnight cultures, at room temperature, were diluted to a ND of 5 and incubated at $37^{\circ} \mathrm{C}$. At a ND of $50\left(7 \times 10^{7}\right.$ c.f.u. $\left.\mathrm{ml}^{-1}\right)$, cells in a $3 \mathrm{ml}$ sample were sedimented, resuspended in $1 \mathrm{ml}$ SMMAD, transferred to $42^{\circ} \mathrm{C}$ in shallow layers (inclined tube) and converted to protoplasts by addition of lysozyme, at a final concentration of $200 \mu \mathrm{g} \mathrm{ml}^{-1}$, and incubation for 30 min without shaking. Already after $15 \mathrm{~min}$, protoplasts represented more than $99 \%$ of the population. Counting with a Petroff-Hausser chamber revealed that each c.f.u. in $\mathbf{L}$ medium yielded approximately two protoplasts. Protoplasts were centrifuged, and gently resuspended in SMMAD medium at a concentration of $4 \times 10^{9} \mathrm{ml}^{-1}$. Then $0.05 \mathrm{ml}$ samples from each partner were mixed in a new tube. After addition of $0.9 \mathrm{ml} \mathrm{PEG}, 40 \%(\mathrm{w} / \mathrm{v})$ in SMMD, the mixture was vigorously shaken and left for $2 \mathrm{~min}$ at room temperature. Samples $(0 \cdot 1 \mathrm{ml})$ of $10^{-4}, 10^{-5}$ and $10^{-6}$ dilutions in SMMAD were spread on RD medium, supplemented with requirements of both partners, and incubated at $37^{\circ} \mathrm{C}$. Spreading of $0.1 \mathrm{ml}$ samples of the $10^{-2}$ dilution on plates of $\mathrm{L}$ medium yielded fewer than 10 colonies, confirming the low numbers of osmotically resistant cells. After $3 \mathrm{~d}$ incubation at $37^{\circ} \mathrm{C}$, colonies, heterogeneous in size, as well as microcolonies corresponding to $\mathrm{L}$ forms, were observed. Well-isolated and circular colonies were transferred with toothpicks onto three minimal TS media containing $5 \mu \mathrm{g}$ DNAase $\mathrm{I} \mathrm{ml}^{-1}$; two plates, the 'parental' ones, were supplemented with requirements of one or the other of the partners (Fig. 1). After overnight incubation at $37^{\circ} \mathrm{C}$, colonies were classified following criteria given in Fig. 1. This figure also describes the determination of the unexpressed chromosome in biparental colonies. Appropriate colonies on RD, as well as on parental plates of the first test, were resuspended in $0.3 \mathrm{ml} \mathrm{L}$ medium containing $15 \%(\mathrm{v} / \mathrm{v})$ glycerol, and stored at $-80^{\circ} \mathrm{C}$. Isolation of CDs proceeded according to the same protocol with the following differences: SMMD was used throughout the experiment, protoplasts were obtained at $37^{\circ} \mathrm{C}$, and cell wall was regenerated on minimal medium $\mathrm{mR2}$.

Stabilization of unstable NCD cells. To stabilize both the silent and the speaking chromosomes, $\mathbf{S}$ medium supplemented with the requirements of the expressed chromosome was inoculated with a $0.1 \mathrm{ml}$ sample of the frozen NCD suspension (see above) and incubated at $37^{\circ} \mathrm{C}$ or $27^{\circ} \mathrm{C}$ (see below). At a cell concentration of about $2 \times 10^{8}$ $\mathrm{ml}^{-1}$, the culture was diluted about 1000 -fold into the same medium and further incubated. Overnight, the temperature was lowered to $27^{\circ} \mathrm{C}$, so as to maintain cells in the exponential growth phase. After several cycles, amounting to 35 to 55 generation times, i.e. about $72 \mathrm{~h}$, the culture was allowed to grow to a concentration of $1.5 \times 10^{8}$ c.f.u. $\mathrm{ml}^{-1}$. A $1 \mathrm{ml}$ sample was supplemented with $15 \%(\mathrm{v} / \mathrm{v})$ glycerol, frozen and stored at $-80^{\circ} \mathrm{C}$. Appropriate dilutions, in the same medium, spread on plates of TS medium containing the supplements of the stabilization medium, as well as on plates of $\mathrm{L}$ medium, provided identical high titres. To quantify possible rare segregants which had inherited only the genome of the parent undergoing counterselection, $0.1 \mathrm{ml}$ samples of $10^{\circ}, 10^{-1}$ and $10^{-2}$ dilutions were spread on unsupplemented TS plates, as well as on those containing the requirements of the parent which had provided the silent chromosome. All plates contained $5 \mu \mathrm{g}$ DNAase $\mathrm{I} \mathrm{ml}^{-1}$ and were incubated at $37^{\circ} \mathrm{C}$.

Self-fusion of stabilized NCD cells. A population of protoplasts (see Protoplast fusion) of a stabilized NCD was mixed in a 1 to 9 ratio with PEG and the fusion protocol rigorously followed (Guillén $e t$ al., 1985). Colonies regenerated on RD medium were tested by replica-plating on appropriately supplemented TS plates and not by transfer with toothpicks.

Quantitative DNA-DNA hybridization. Chromosomal DNA was prepared from stationary-phase cultures in $\mathrm{S}$ medium according to Marmur (1961) and purified on a $\mathrm{CsCl}$ gradient (Maniatis et al., 1982). Plasmids were prepared as described by Del Sal et al. (1988) and the radioactive probes synthesized by the random priming method (Feinberg \& Vogelstein, 1983). Restriction fragments, purified by a Geneclean kit (supplied by Lucerna Chem, Switzerland), were labelled with $5^{\prime}-\left[\alpha-{ }^{32} P\right]$ deoxyadenosine triphosphate. Quantitative hybridization was performed according to Young et al. (1989).

Spreading of PEG-treated mixed bacterial populations. Two different bacterial populations were treated essentially according to the protocol of protoplast fusion described above. However, cells were cultivated as described by Schaeffer $e t$ al. (1976) in NB medium and aerated by shaking in an Erlenmeyer flask. The lysozyme treatment, however, was omitted.

Subcloning. Subcloning was performed according to Hotchkiss \& Gabor (1980). A $0 \cdot 1 \mathrm{ml}$ sample of a biparental or prototrophic colony suspension from regeneration medium, frozen at $-80^{\circ} \mathrm{C}$ (see above), was inoculated in NB medium containing $5 \mu \mathrm{g}$ DNAase $\mathrm{I} \mathrm{ml}^{-1}$ and incubated with shaking in an Erlenmeyer flask at $37^{\circ} \mathrm{C}$. When the ND reached 40 to 100 , i.e. 4 to 6 h or 6 to 8 generation times later, the culture was streaked out for isolated colonies on plates of $\mathrm{L}$ medium. After overnight incubation at $30^{\circ} \mathrm{C}$, the phenotype of 50 well-isolated and circular colonies was determined by transfer with toothpicks on to appropriately supplemented TS media; parent, recombinant and biparental colonies were recorded (see Fig. 1)

Plating of mixed cultures. Overnight cultures, grown at room temperature, were diluted into $L$ medium to a ND of 2 and incubated at $37^{\circ} \mathrm{C}$ to a ND of 50 . Several $10^{-4}$ to $10^{-5}$ dilutions were prepared in the same medium. Corresponding dilutions of each partner were mixed in a new tube, and $0.1 \mathrm{ml}$ samples were spread on plates of $L$ medium. After overnight incubation at $30^{\circ} \mathrm{C}$, well-isolated and circular colonies were tested for their parent, recombinant or biparental phenotype (see Fig. 1).

DNA content per cell. An overnight culture, grown at $24^{\circ} \mathrm{C}$, was diluted to a ND of 2 into TS medium and incubated at $37^{\circ} \mathrm{C}$. Thy ${ }^{+}$cells were labelled with $0 \cdot 1 \mu \mathrm{Ci}\left[2{ }^{-14} \mathrm{C}\right]$ thymidine $\mathrm{ml}^{-1}$ in the presence of 1.5 mM-2'-deoxyadenosine (Budman \& Pardee, 1967). Incorporation of isotope into material precipitable in $5 \%(w / v)$ trichloroacetic acid was measured by scintillation counting. At a ND of 100, (i) DNA content, (ii) dry weight, and (iii) the average cell length were determined in duplicate.

(i) DNA content. After addition of $\mathrm{NaN}_{3}$ (final concentration $0.05 \mathrm{M}$ ) to a $10 \mathrm{ml}$ sample, cells were harvested by centrifugation at $4{ }^{\circ} \mathrm{C}$ and unincorporated radioactive thymidine eliminated by two washes with $10 \mathrm{ml} 0.5 \mathrm{M}-\mathrm{HClO}_{4}$ at $0{ }^{\circ} \mathrm{C}$. The pellet was resuspended in $10 \mathrm{ml} 0.5 \mathrm{M}-$ $\mathrm{HClO}_{4}$ at $0{ }^{\circ} \mathrm{C}$ and recentrifuged after $30 \mathrm{~min}$. Cells were resuspended in $2 \mathrm{ml} 0.5 \mathrm{M}-\mathrm{HClO}_{4}$, and incubated for $20 \mathrm{~min}$ at $70^{\circ} \mathrm{C}$ (DNA extraction). After cooling to room temperature, the sample was centrifuged and DNA in the supernatant was determined by the diphenylamine method, using 2 '-deoxyadenosine as standard. 


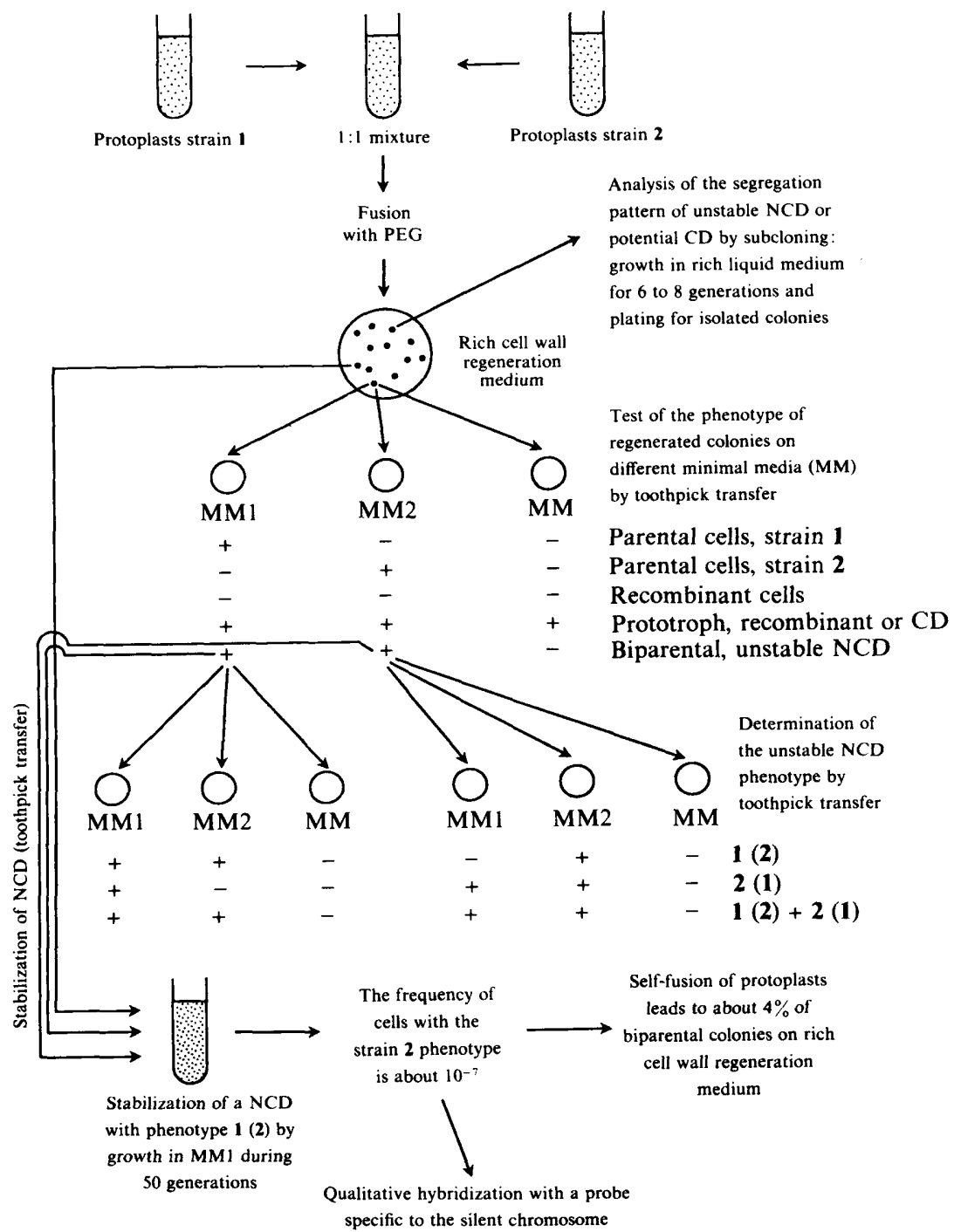

Fig. 1. Method for construction and identification of NCDs (Hotchkiss \& Gabor, 1980; Guillén et al., 1985). The first toothpick transfer allows the identification of exfusant types on the regeneration plate. This stage of the characterization is obviously equivalent to a stabilization step. Thus, proceeding to 'full' stabilization, from either the original exfusant colony or the first subculture, leads essentially to the same result. In experiments described in Table 3, the origin of the colony used for the stabilization - regeneration plate or subculture - is specified. The NCD phenotype deduced from the second toothpick transfer refers to the nature of cells contained both in the original biparental colony and in that obtained after the first toothpick transfer. MM1 and MM2 are supplemented with requirements of strain 1 and 2 , respectively. The number in parentheses refers to the silent chromosome. + , Growth; - , no growth.

(ii) Dry weight. The method of Tilby (1978) was used. Sartorius cellulose acetate filters $(0.45 \mu \mathrm{m}$ pore size) were washed with doubledistilled water, dried at $60^{\circ} \mathrm{C}$ for $5 \mathrm{~h}$, and weighed. Samples $(20 \mathrm{ml})$ of a culture were collected on filters previously soaked in double-distilled water and placed on a filter manifold (Millipore). The filters were weighed after drying to a constant weight overnight at $60^{\circ} \mathrm{C}$.

(iii) Cell length. Cells from a $2 \mathrm{ml}$ sample were harvested on a $0.45 \mu \mathrm{m}$ Sartorius filter, fixed by two rinses with $5 \mathrm{ml} \mathrm{5 \%}(\mathrm{w} / \mathrm{v})$ trichloroacetic acid at $0{ }^{\circ} \mathrm{C}$, and washed twice with $5 \mathrm{ml}$ double-distilled water at $0{ }^{\circ} \mathrm{C}$. Resuspension of the cells in $2 \mathrm{ml}$ potassium phosphate buffer $(0.05 \mathrm{M}$, $\mathrm{pH} 7.5$ ) containing $2 \mathrm{mg}$ trypsin $\mathrm{ml}^{-1}$ and incubation for 20 to $40 \mathrm{~min}$ at $37^{\circ} \mathrm{C}$ removes much of the cytoplasm and allows visualization of cell wall and septa by phase-contrast microscopy. The length of the cells adsorbed on slides was measured on a Zeiss standard microscope with a $\times 100$ objective, and an eyepiece fitted with a micrometric scale. Fifty cells per sample were measured, with a precision of about $0.2 \mu \mathrm{m}$.

\section{Results}

Isolation and characterization of exfusant colonies with a biparental phenotype; search for stable NCDs.

To obtain stable NCDs, we followed the method of Guillén et al. (1985) (Fig. 1 and Methods). In two crosses (Table 2), exponentially growing populations of parent 
Table 2. Analysis of protoplast fusion products

\begin{tabular}{|c|c|c|c|c|c|c|}
\hline \multirow[b]{2}{*}{ Cross* } & \multirow[b]{2}{*}{ Parent strains } & \multirow{2}{*}{$\begin{array}{l}\text { Percentage } \\
\text { of protoplasts } \\
\text { regenerated } †\end{array}$} & \multirow{2}{*}{$\begin{array}{c}\text { Exfusant } \\
\text { colonies tested } \ddagger\end{array}$} & \multicolumn{3}{|c|}{ Colony phenotype§ (\%) } \\
\hline & & & & S15 & $\mathrm{M} 22$ or $\mathrm{S} 1 \Delta 1$ & Biparental \\
\hline 1 & S15 and M22 & 23 & 300 & $55 \cdot 7$ & $40 \cdot 3$ & $4 \cdot 0$ \\
\hline 2 & S 15 and S $1 \Delta 1$ & 32 & 300 & $90 \cdot 3$ & $7 \cdot 0$ & $2 \cdot 7$ \\
\hline
\end{tabular}

* Concentrated parental protoplasts, mixed in a $1: 1$ ratio, were treated with PEG, diluted and plated onto RD medium. $\dagger$ Mean protoplast numbers of the two partners were determined in a counting chamber.

$\ddagger$ Plates from $10^{-4}$ and $10^{-5}$ dilutions, comprising about 500 and 70 colonies respectively, were used.

$\S$ The colonies examined did not contain those with a recombinant or a prototrophic phenotype.

Table 3. Stabilization of putative NCDs (biparental colonies) by growth in minimal medium supplemented with the requirements of the appropriate parent

\begin{tabular}{|c|c|c|c|c|c|c|}
\hline Cross* & $\begin{array}{c}\text { Biparental } \\
\text { colonyt, no. }\end{array}$ & $\begin{array}{c}\text { Unstable } \\
\text { NCD phenotype } \neq\end{array}$ & $\begin{array}{l}\text { Source (medium) } \\
\text { of the } \\
\text { biparental colony§ }\end{array}$ & $\begin{array}{l}\text { Stabilization } \\
\text { medium } \|\end{array}$ & $\begin{array}{c}\text { No. of } \\
\text { generations } \\
\text { in stabilization } \\
\text { medium }\end{array}$ & $\begin{array}{l}\text { Frequency of } \\
\text { segregants } \\
\text { selected } \\
\text { against }\end{array}$ \\
\hline 1 & $\begin{array}{r}46 \\
87 \\
97 \\
152 \\
215\end{array}$ & $\begin{array}{c}\text { S15 (M22) + M22 (S15) } \\
\text { S15 (M22) + M22 (S15) } \\
\text { S15 (M22) + M22 (S15) } \\
\text { S15 (M22) } \\
\text { S15 (M22) + M22 (S15) }\end{array}$ & $\begin{array}{l}\text { S15 } \\
\text { RD } \\
\text { RD } \\
\text { RD } \\
\text { M22 }\end{array}$ & $\begin{array}{l}\text { S15 } \\
\text { S15 } \\
\text { M22 } \\
\text { S15 } \\
\text { M22 }\end{array}$ & $\begin{array}{l}54 \\
46 \\
40 \\
44 \\
41\end{array}$ & $\begin{aligned} & 7 \times 10^{-7} \\
& 4 \times 10^{-8} \\
& 2 \times 10^{-3} \\
< & 4 \times 10^{-8 * *} \\
< & 6 \times 10^{-8 * *}\end{aligned}$ \\
\hline 2 & $\begin{array}{r}69 \\
69 \\
106 \\
116 \\
228 \\
229\end{array}$ & 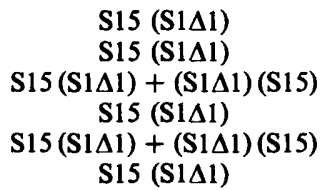 & $\begin{array}{l}\text { RD } \\
\text { S15 } \\
\text { RD } \\
\text { S15 } \\
\text { S1 } 11 \\
\text { S15 }\end{array}$ & $\begin{array}{l}\text { S15 } \\
\text { S15 } \\
\text { S1 } 11 \\
\text { S15 } \\
\text { S1 } 11 \\
\text { S15 }\end{array}$ & $\begin{array}{l}35 \\
52 \\
43 \\
50 \\
47 \\
52\end{array}$ & $\begin{aligned} 1 & \times 10^{-6} \\
<3 & \times 10^{-8 * *} \\
5 & \times 10^{-7} \\
<3 & \times 10^{-8 * *} \\
5 & \times 10^{-4} \\
1 & \times 10^{-7}\end{aligned}$ \\
\hline
\end{tabular}

* Refers to crosses presented in Table 2.

† Biparental colonies were isolated from plates seeded with the $10^{-5}$ dilution, with the exception of nos 215,228 and 229 , which originate from a $10^{-4}$ dilution (see Table 2).

† See Fig. 1.

$\S \mathrm{RD}, \mathrm{S} 15, \mathrm{M} 22$ and S1 11 refer to RD plates or TS minimal medium supplemented so as to allow growth of strain S15, M22 and $S 1 \Delta 1$, respectively.

$\| S 15, M 22$ and $S 1 \Delta 1$ refer to $S$ minimal medium supplemented with the requirements of strains S15, M22 and S1 1 , respectively.

I Ratio of c.f.u. on TS medium supplemented with the requirements of the parent selected against, to those obtained on TS medium containing the supplements of the stabilization medium. No colonies were present on unsupplemented TS plates.

** No segregants were observed.

strains were converted into protoplasts, mixed, induced to fuse in the presence of PEG, and spread on RD medium. Well-isolated and circular colonies of exfusants, which regenerated at frequencies around $30 \%$, were processed and classified as parental and biparental according to Fig. 1 (Table 2).

Stabilization of apparent NCDs with a given phenotype, harboured by biparental colonies, was achieved by resuspension of a given colony in minimal medium supplemented with the requirements associated with the expressed chromosome, followed by 40 to 50 generations of exponential growth. For the 1 (2) +2 (1) NCD phenotype (see Fig. 1), the stabilization medium was chosen arbitrarily. Eleven putative stable NCDs were tested for the presence of segregants with the phenotype selected against during the stabilization procedure. The frequency of such segregants ranged from $\leq 6 \times 10^{-8}$. (i.e. none observed) to $2 \times 10^{-3}$ (Table 3 ). These figures. have been considered (Guillén et al., 1985) as a measure of the rate at which haploid cells containing the formerly silent chromosome segregate from stable diploids.

Presence of the silent chromosome was assessed by self-fusion - protoplasting and PEG treatment - and by quantitative DNA-DNA hybridization (Young et al., 1989). Self-fusion was performed on nine putative stabilized NCDs showing segregation frequencies 
Table 4. Characterization of the genotype of putative stabilized NCDs by quantitative DNA-DNA hybridization

\begin{tabular}{|c|c|c|c|c|c|}
\hline \multirow[b]{2}{*}{ Strain* } & \multirow{2}{*}{$\begin{array}{l}\text { Stable NCD } \\
\text { phenotype }\end{array}$} & \multicolumn{2}{|c|}{ Quantity of hybridized probe (c.p.m.) $\dagger$} & \multicolumn{2}{|c|}{$\begin{array}{l}\text { Hybridization relative to that with } \\
\text { S1 } \Delta 1 \text { DNA }(\%)\end{array}$} \\
\hline & & pHV32 & phe $B, A$ & pHV32 & phe $B, A$ \\
\hline $\mathrm{S} 1 \Delta 1$ & - & 47141 & 15289 & 100 & 100 \\
\hline S15 & - & 170 & 12335 & 0.4 & 81 \\
\hline $69 \ddagger$ & $\mathrm{S} 15(\mathrm{~S} 1 \Delta 1)$ & 211 & 13861 & 0.5 & 91 \\
\hline 116 & $\mathrm{~S} 15(\mathrm{~S} 1 \Delta \mathrm{l})$ & 229 & 14814 & 0.5 & 97 \\
\hline 228 & S $1 \Delta 1(\mathrm{~S} 15)$ & 43098 & 16129 & 91.4 & 106 \\
\hline 229 & S15 (S1 $1 \Delta)$ & 249 & 16263 & 0.5 & 106 \\
\hline
\end{tabular}

* Numbers refer to stabilized NCDs presented in Table 3. DNA was prepared from stationary-phase cultures in S medium. † Counts obtained with $0.15,0.5$ and $1.5 \mu \mathrm{g}$ of chromosomal DNA were normalized to $0.5 \mu \mathrm{g}$ and their mean calculated. All measurements were within $\pm 10 \%$ of the mean. Background was 112 and 41 c.p.m. with pHV 32 and pheB,A probes, respectively. Probe pHV 32 is specific to the $S 1 \Delta 1$ genome (see Methods).

† Stabilized from the RD plate (see Table 3).

between $10^{-6}$ and $10^{-8}$, which are characteristic of stable NCDs (Guillén et al., 1985). Among more than 450 isolated and circular regenerated colonies tested for each NCD, none exhibited the phenotype associated with the putative silent chromosome. Thus, no such chromosome was reactivated, suggesting that the vast majority of cells subjected to self-fusion were haploid. Quantitative hybridization tests, performed on four putative stabilized NCDs from cross 2 , were incompatible with a diploid structure (Table 4). Indeed, were the populations to consist of diploid cells, the ratio of the hybridized quantities of the reference DNA probe, present on both chromosomes, to that of plasmid pHV32, present on the S1 $\Delta 1$ chromosome only (see Methods), should be 2:1 whether pHV32 is localized on the silent or on the speaking chromosome. In fact, this ratio was found to be $1: 1$ when pHV32 is localized on the speaking chromosome and $1: 0$ when it is assigned to a putative silent one.

In conclusion, cells with a silent chromosome, if present at all, in the population of a putative stabilized NCD, are too rare to be detected by the methods used. However, the question remains open of the possible mixed nature of the original biparental colonies and an impoverishment in cells of one of the partners during the stabilization procedure.

\section{Plating mixtures of parental cells generates colonies with} a biparental phenotype.

To test whether the biparental phenotype can be accounted for by the presence of both parents in the original colony on the regeneration plate, we studied populations obtained by mixing whole cells of both parents. When the procedure for protoplast fusion, with the omission of lysozyme treatment, was applied to strains $S 15$ and $S 1 \Delta 1$, biparental colonies were obtained at frequencies comparable to those characteristic of protoplast fusion (Table 5, experiments 1 and 2). Plating about 45 cells per plate yielded about $1 \%$ of isolated and circular colonies with a biparental phenotype (Table 5). The latter were subcloned according to Hotchkiss \& Gabor (1980), i.e. resuspended in rich medium supplemented with DNAase, incubated for 6 to 8 generations and streaked for isolated colonies. Analysis of circular colonies revealed not only subclones of $\mathrm{S} 15$ and $\mathrm{S} 1 \Delta 1$ cells, but also up to $7 \%$ of colonies with a biparental phenotype (Table 5), an observation considered as important evidence of the relative stability of NCDs (Hotchkiss \& Gabor, 1980). A rare recombinant, observed in one subcloning, could have arisen by genetic exchange between cells of a mixed population.

If the presence of mixed colonies on plates seeded with 20 to 30 cells of each parent (Table 5, experiments 3 to 5) was surprising, their presence after subcloning suggested some cell-to-cell sticking. Since the mixing of relatively concentrated cultures in the presence of PEG could have allowed collisions between both parental cells and their clumping prior to spreading, we diluted the initial cultures to cell densities around $10^{3} \mathrm{ml}^{-1}$. The dilutions were mixed in absence of PEG and spread on plates. Again, colonies with a biparental phenotype, in this case due solely to coincidence, were identified. As expected, their proportion was a function of the number of cells per plate (Table 6), suggesting that two cells had a small but not negligible probability of being seeded within a critical surface area $S$, so as to generate a circular mixed colony. If $x$ and $y$ are the numbers of cells of the two partners seeded on a plate with a surface area of 
Table 5. Generation of biparental colonies from mixtures of PEG-treated cells of two different strains; persistence of the biparental phenotype after subcloning

\begin{tabular}{|c|c|c|c|c|c|c|c|c|}
\hline \multirow[b]{3}{*}{ Expt* } & \multirow{3}{*}{$\begin{array}{c}\text { No. of } \\
\text { colonies tested }\end{array}$} & \multirow{3}{*}{$\begin{array}{l}\text { Mean no. of } \\
\text { colonies per plate } \dagger \\
\text { (standard deviation) }\end{array}$} & & & & \multicolumn{3}{|c|}{ Subcloning of biparental colony } \\
\hline & & & \multicolumn{3}{|c|}{ Colony phenotype (\%) } & \multirow{2}{*}{$\begin{array}{l}\text { No. } \\
\text { tested } \ddagger\end{array}$} & \multicolumn{2}{|c|}{$\begin{array}{l}\text { Phenotype among } \\
\text { tested subclones }(\%)\end{array}$} \\
\hline & & & $\mathbf{S} 15$ & S $1 \Delta 1$ & Biparental & & Biparental & Recombinant \\
\hline 1 & 486 & & $75 \cdot 7$ & 22.0 & $2 \cdot 3$ & ND & & \\
\hline 2 & 415 & & $68 \cdot 2$ & 29.9 & 1.9 & ND & & \\
\hline 3 & 400 & $43(5 \cdot 2)$ & $45 \cdot 0$ & 54.0 & 1.0 & 4 & $0,0,5,7 \S$ & $0,0,0,0$ \\
\hline 4 & 500 & $47(7 \cdot 3)$ & $59 \cdot 2$ & $40 \cdot 2$ & 0.6 & 3 & $0,0,2$ & $0,0,0$ \\
\hline 5 & 500 & $38(5.9)$ & $43 \cdot 6$ & $55 \cdot 6$ & 0.8 & 4 & $0,2,2,4$ & $0,0,0,2 \pi$ \\
\hline
\end{tabular}

* Concentrated S15 and S1 $\Delta 1$ bacteria, mixed in a $1: 1$ ratio, were treated with PEG and plated on RD medium. In experiment 2, the treatment with PEG was omitted. In experiment 5, cells were incubated in SMMD instead of SMMAD buffer and spread on $\mathbf{L}$ instead of RD medium.

$\dagger$ In experiments 1 and 2 , colonies were sampled from plates seeded with $10^{-5}, 0.5 \times 10^{-5}$ and $10^{-6}$ dilutions which, as in protoplast fusion, contained about 300,150 and 30 colonies, respectively. In experiments 3,4 and 5 , all plates were seeded with a $10^{-6}$ dilution of the cell mixture.

$\ddagger$ ND, Not done.

$\S$ Each number refers to a different colony tested. The number of subclones tested varied between 37 and 75 .

T The only colony not growing on the two minimal TS media allowing growth of the parent strains was found to carry the metB5 marker of strain $\mathbf{S} 1 \Delta 1$, in addition to the auxotrophic markers of S15.

Table 6. Biparental colonies obtained when diluted cultures of strains S15 and S141 were mixed and plated

\begin{tabular}{|c|c|c|c|c|c|}
\hline \multirow[b]{2}{*}{ Expt* } & \multirow{2}{*}{$\begin{array}{c}\text { Mean no. of } \\
\text { colonies per plate } \\
\text { (standard deviation) }\end{array}$} & \multirow{2}{*}{$\begin{array}{c}\text { No. of } \\
\text { colonies tested } \dagger\end{array}$} & \multicolumn{3}{|c|}{ Colony phenotype $(\%)$} \\
\hline & & & S15 & S $1 \Delta 1$ & Biparental $\ddagger$ \\
\hline 1 & $61 \quad(7 \cdot 2)$ & 2098 & $50 \cdot 00$ & $49 \cdot 76$ & $0 \cdot 24$ \\
\hline 2 & $183(13.9)$ & 2000 & 53.40 & $45 \cdot 80$ & 0.80 \\
\hline 3 & $363(22 \cdot 6)$ & 2000 & $52 \cdot 60$ & $46 \cdot 30$ & $1 \cdot 10$ \\
\hline
\end{tabular}

$* 10^{-4}$ to $10^{-5}$ dilutions of $S 15$ and $S 1 \Delta 1$ cultures were mixed in a $1: 1$ ratio and plated.

$\dagger$ Isolated colonies were tested either by replica-plating (experiment 1) or by toothpick transfer (experiments 2 and 3). Contiguous colonies were excluded from the analysis, because of the risk of crosscontamination.

$\ddagger$ When plates were seeded with greater numbers of cells (experiments 2 and 3 ), the more densely populated areas of the plates, which necessarily have the highest proportion of mixed colonies, were underrepresented in the analysis because of the increased proportion of contiguous colonies. This could account for the proportion of biparentals increasing in a manner that was related linearly rather than to the square of the number of colonies per plate, as predicted by the formula (see text).

$5675 \mathrm{~mm}^{2}$, the observed number $N$ of biparental colonies is related to $S$ as follows:

$$
N=\frac{x \cdot y}{5675} \cdot S
$$

We have assumed that if $x$ and $y$ are relatively small, the total critical surface associated with $x$ cells will be $x \cdot S$, and for a cell seeded on a plate the probability of its falling within $x \cdot S$ is $x \cdot S / 5675$. Introducing figures from experiments 1,2 and 3 (Table 6) provides $S=0.89,1.00$ and $0.71 \mathrm{~mm}^{2}$, respectively. Thus, cells separated by less than $1 \mathrm{~mm}$ would generate a circular colony. In good agreement with this, observations with a stereomicroscope have shown that two microcolonies can generate a circular colony if their centres are less than $0.4 \mathrm{~mm}$ apart (Fig. 2). The apparent difference between the calculated figure of about $1 \mathrm{~mm}$ and the observed distance of about $0.4 \mathrm{~mm}$ required for coincidence is probably due to experimental errors. However, phenomena such as surface tension could have enhanced displacement and encountering of neighbouring cells. Incidentally, when experiments involved partners characterized by different colony morphologies, sectored colonies were formed (not shown). 


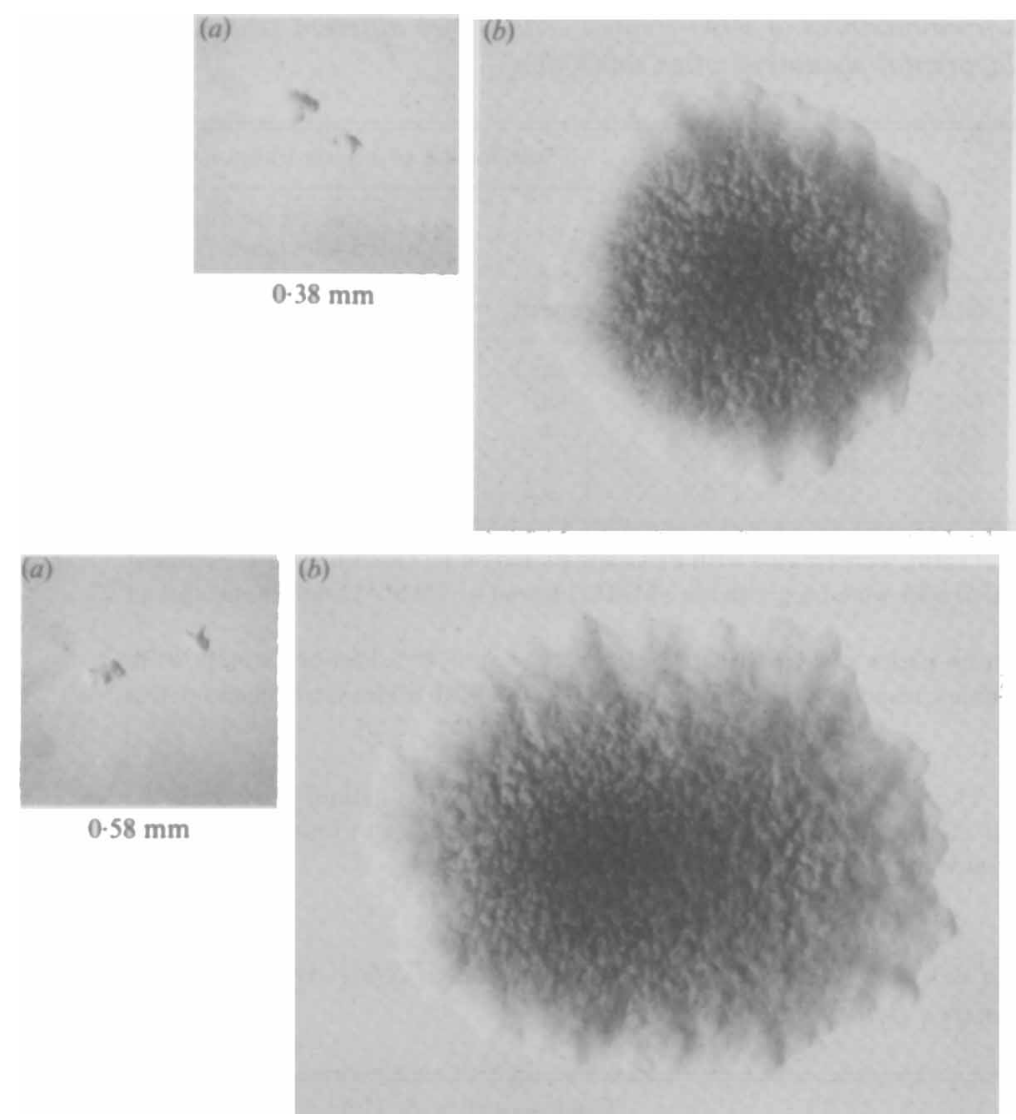

Fig. 2. Merging of two microcolonies into a single colony. Micrographs were obtained with a Zeiss DRC stereomicroscope: pictures taken after $6 \mathrm{~h}$ at $37^{\circ} \mathrm{C}(a)$, and after an additional $15 \mathrm{~h}$ at $30^{\circ} \mathrm{C}(b)$, correspond to the same magnification. The distance between centres of microcolonies is given under the corresponding micrograph.

Table 7. Determination of DNA/dry weight ratio in exponentially growing putative NCD and CD cells

Cells were grown in appropriately supplemented TS medium with a generation time of 40 to $45 \mathrm{~min}$. Cultures were processed at a ND of $100\left(1.5 \times 10^{8}\right.$ c.f.u. $\mathrm{ml}^{-1}$ ).

\begin{tabular}{|c|c|c|c|c|}
\hline Strain & $\begin{array}{l}\text { Cell length* } \\
(\mu \mathrm{m})\end{array}$ & $\begin{array}{l}\text { Dry weight } \\
\left(\mathrm{mg} \mathrm{ml}^{-1}\right)\end{array}$ & $\underset{\left(\mu \mathrm{g} \mathrm{ml}^{-1}\right)}{\text { DNA }}$ & $\begin{array}{c}\text { DNA/dry weight } \\
(\%)\end{array}$ \\
\hline 168 & $3 \cdot 0$ & 0.26 & $3 \cdot 2$ & $1 \cdot 2$ \\
\hline S15 & $3 \cdot 2$ & 0.25 & $3 \cdot 1$ & 1.2 \\
\hline $\mathrm{S} 15(\mathrm{~S} 1 \Delta 1)$ & $3 \cdot 3$ & 0.24 & $3 \cdot 1$ & $1 \cdot 3$ \\
\hline CD1 & $3 \cdot 1$ & 0.23 & $2 \cdot 6$ & $1 \cdot 1$ \\
\hline $\mathrm{CD} 2$ & $3 \cdot 2$ & 0.22 & $2 \cdot 5$ & $1 \cdot 1$ \\
\hline CD3 & $3 \cdot 1$ & 0.24 & $2 \cdot 6$ & $1 \cdot 1$ \\
\hline
\end{tabular}

* Following trypsin treatment, 50 cells were measured with an eyepiece fitted with a micrometric scale. For all strains, cell diameters were around $0.8 \mu \mathrm{m}$.

$\dagger$ Measured by the diphenylamine method. DNA extraction was about $95 \%$ as determined by $\left[2-{ }^{14} \mathrm{C}\right]$ thymidine labelling.

In conclusion, we have shown that colonies with the biparental phenotype occur in mixed populations with frequencies comparable to those obtained with exfusants. Indeed, comparison of Tables 2 and 5 strongly suggests that the vast majority of biparental colonies are formed of mixed parental populations, due to coincidence or protoplast clumping.
Determination of the DNA content of cells found to be $N C D$

Our attempts to obtain NCDs were unsuccessful and revealed that, if true diploids occur, they do so at much lower frequencies than hitherto suggested. Therefore, we determined the DNA content per cell of strain S15 
(S1 1 1) (Lopez et al., 1986), reported to be a stable diploid. Exponentially growing cells of this strain, as well as those of two reference haploid strains, S15 and 168, were found to have the same average length and the same DNA to dry weight ratio (Table 7).

\section{DNA content of cells identified as $C D$}

Our search for NCD exfusants was unsuccessful. However, the hypothesis of the existence of such entities implies not only a peculiar nucleoplasmic organization but also a mechanism, hitherto unknown in prokaryotes, by which one of the chromosomes is silenced. Thus, a CD exfusant not requiring a silenced chromosome may be more easily obtainable. To investigate this possibility, we fused strains $S 15$ and $S 1 \Delta 1$ according to the procedure of Sanchez-Rivas (1982) and identified several potential CD colonies. The latter grew on non-supplemented minimal medium and differed from clearly prototrophic recombinants in the segregation of S15 subclones. Comparison of the average quantity of DNA per cell of three CDs to that of control haploid cells during exponential growth did not reveal any significant difference (Table 7). Thus, persistence of cells of the S15 parent in the absence of supplements needed for its growth on minimal medium may result from crossfeeding.

\section{Discussion}

Our attempts to obtain positive evidence in favour of diploidy in B. subtilis cells with the NCD or the CD phenotype were unsuccessful. Within the limits of the methods used - self-fusion, DNA-DNA hybridization and determination of the DNA to mass ratio - all exfusants studied, including one previously reported as a stable NCD, were found to consist of haploid cells. We have shown further that mixed populations of cells satisfy, both qualitatively and quantitatively, the operational definition of NCDs. The presence of mixed colonies among exfusants is fully accounted for by coincidence, by cell-to-cell sticking and by phenomena inherent to cell spreading. Therefore, we believe that, if true diploids were to occur among exfusants, they must do so at a frequency appreciably lower than that characteristic of biparental or prototrophic colonies.

In the light of the foregoing, we consider useful a brief review and discussion of the essential evidence on which the hypothesis of NCD and CD cells is based. It should be stressed that the hypothesis of the existence of mixed colonies among exfusants was envisaged previously but dismissed on the basis of reconstruction experiments involving spreading of mixed populations (Hotchkiss \&
Gabor, 1980). Unfortunately, these crucial experiments, which led the authors to put forward an alternative explanation, were not presented in sufficient detail to be re-evaluated. The operational definition of a NCD and the evidence in favour of the diploid nature of colonies with the biparental phenotype rest essentially upon analyses of segregation patterns of exfusants from parents carrying complementary polyauxotrophic and, in some instances, different antibiotic resistance markers (Hotchkiss \& Gabor, 1980; Gabor \& Hotchkiss 1982, 1983). In reported experiments (Table 4 of Hotchkiss \& Gabor, 1980), biparental colonies were inoculated into DNAase-containing liquid medium, and incubated for 6 to 8 generations. After this, subclones underwent several subcultures in various selective DNAase-containing media by successive transfer from plate to plate with the aid of toothpicks. It has been generally assumed that one or several passages on appropriately supplemented minimal media and, in particular, on those ensuring an antibiotic-mediated counterselection, would eliminate any segregants or contaminants with the sensitive or unsupplemented phenotypes. In other experiments $(\mathrm{Ga}-$ bor \& Hotchkiss, 1983), about 50 subclones of each exfusant were characterized, further subcloned, and tested for segregation of late recombinants. Maintenance of the character(s) selected against, supposedly encoded by the silent chromosome, and/or appearance of late recombinants was interpreted in favour of diploidy. However, our control experiments showed that the subcloning and the purification procedure used in these experiments are inadequate for the following reasons. (i) As reported (see Results), about $5 \%$ of isolated colonies, obtained by streaking out a mixed population, contain both types of cells. (ii) A toothpick transfers about $10^{6}$ cells from a colony consisting of about $10^{8}$ cells, and the incubation of such an inoculum on selection plates allows the development of the contaminating partner through cross-feeding (not presented). (iii) The presence in plates of streptomycin or rifampicin has no bactericidal effect on non-growing cells (not presented; Eng et al., 1991). (iv) Subclones observed to have a recombinant phenotype were most likely transferred from the original colony and/or generated by transformation in mixed colonies. A recent contribution by Romanowski et al. (1991) provides firm evidence that on solid surfaces DNA is excreted and poorly accesssible to DNAase. Development of competence in analogous conditions (Lorenz et al., 1988) allows transformation and formation of recombinants in mixed populations.

The physical evidence in favour of the silenced chromosome, involving protoplast fusion between a nonlysogenic and a $\phi 105$ lysogenic partner (Guillén et al., 1985) could have another explanation. When the presence of $\phi 105$, thought to be localized on the silenced 
chromosome, was established in NCDs by DNA-DNA hybridization, the possibility that the partner providing the speaking chromosome had been lysogenized by $\phi 105$ released through spontaneous induction was not considered.

Reconstruction experiments (not presented) and determination of the cell DNA content of exfusant colonies revealed that mixed colonies, consisting of a haploid prototrophic recombinant and various auxotrophs maintained by cross-feeding, satisfy the operational definition of CDs. Initially (Schaeffer et al., 1976), prototrophic colonies were identified by replica-plating a lawn of exfusants, obtained on rich regeneration medium, onto a minimal medium. After purification by two successive toothpick transfers onto the identical minimal medium, colonies were resuspended in nutrient broth, incubated for 10 generations, plated on rich medium and screened for the presence of auxotrophic segregants by replicaplating. Eleven prototrophic exfusants were found not to segregate auxotrophs. They were attributed to recombinant haploid cells. Later (Lévi, 1978; Lévi-Meyrueis et al., 1980), screening of 219 prototrophic exfusants, obtained from three independent crosses, has revealed that about $10 \%$ of them, purified as described here, did segregate auxotrophic colonies. Three prototrophic subclones, apparently breeding true, were analysed further (Lévi, 1978). They were obtained from an original exfusant characterized by a massive segregation of auxotrophs. The three chosen colonies were inoculated into rich medium and the transforming activity of their DNA was determined. Appearance of recombinants with most, if not all, of the parental auxotrophic markers (Lévi, 1978; Lévi-Meyrueis et al., 1980) was interpreted in favour of the existence of CDs. However, this observation could be accounted for by persistence of contaminating cells and, as the concentration of the latter was as high as $50 \%$ (Lévi, 1978), by the presence of mixed colonies among the subclones. Subsequently, the isolation of CDs was simplified (Sanchez-Rivas, 1982): exfusant prototrophic recombinants were directly selected on an impoverished regeneration medium and replicated once onto a minimal medium. The vast majority of exfusants obtained from a $\operatorname{spo0A}$ and a $\mathrm{Spo}^{+}$parent were found to exhibit the $\mathrm{Spo}^{-}$phenotype (Sanchez-Rivas, 1982). Since such exfusants segregated $\mathrm{Spo}^{+}$cells, they were assimilated to $\mathrm{CDs}$, their $\mathrm{Spo}^{-}$phenotype being due to the dominance of $5 p o 0 A$ over $\mathrm{Spo}^{+}$. However, inspection of the genotypes of the two partners - MO220 and S15 suggests a straightforward explanation of this result. The relative proximity of $s p o 0 A$ and $\operatorname{trp} C 7\left(10^{\circ}\right)$ leaves open the possibility of their frequent co-transfer in protoplast fusion crosses which involve whole chromosomes. Thus, generation of $\mathrm{Spo}^{+}$prototrophs would be rather rare. Presence, among $\mathrm{Spo}^{-}$recombinants, of $\mathrm{Spo}^{+}$cells, attributed to haploid segregants, is easily accounted for since the identification procedure involved a sporulation cycle allowing detection of very rare $\mathrm{Spo}^{+}$cells present in the prototrophic colony.

In the light of our observations, the interpretation of experiments so far reported, designed to demonstrate the presence of diploid cells, in particular NCDs, and to study the nature of chromosomal inactivation, is an uncertain undertaking. Experiments based on mixed cultures of unknown proportions in the starting material, and of totally unknown growth physiology, are unlikely to yield reproducible observations. The crucial experiment on the reactivation of the silenced chromosome by proteinase K treatment (Bohin et al., 1982; Guillén et al., 1985), is revealing in this respect since it was apparently never reproduced; Table 3 in Bohin et al. (1982) and Table VII in Guillén et al. (1985) are numerically superimposable, with the exception of one number, strongly suggesting that they refer to the same, unique, experiment. In addition, physiological studies on the nature of chromosome inactivation resting upon $\phi 105$ induction in NCDs by either mitomycin C treatment or use of a thermoinducible mutant of $\phi 105$ are irrelevant; comparison of reported (Guillén et al., 1983) burst-sizes of about $10^{-3}$ to those of about 100 , normally obtained (Rutberg, 1969), confirm that the $\phi 105$ induction protocol used was inadequate.

Observations on protoplast fusion in $B$. megaterium were interpreted in favour of a haploid nature for exfusants (Fodor \& Alföldi, 1976). Reconstruction experiments with whole cells, like those reported here for $B$. subtilis, have revealed that colonies with a biparental phenotype consisted of a mixture of parental cells (Fodor et al., 1983). The relatively high frequency of such colonies - above $10 \%$ - is most likely to be predominantly due to cell-to-cell sticking, enhanced by the slimy capsular material abundant on $B$. megaterium cells. Subsequently, Fleischer \& Vary (1985) have reported the presence of NCDs among exfusants in this organism. Their evidence rests basically on the operational definition of Hotchkiss \& Gabor (1980). A biparental colony is subcloned. Among subclones a biparental colony is subcloned again and the procedure repeated up to 10 times. However, we have shown this method to be inadequate, since subcloning and streaking of a mixed population provides a variable proportion of mixed colonies due to cell-to-cell sticking and coincidence (see above, Table 5). Control experiments with mixtures of whole cells were not performed by Fleischer \& Vary (1985), nor was sufficient attention paid to the contribution of Fodor $e t$ al. (1983). Therefore, we believe that, as in $B$. subtilis, there is no positive evidence in favour of NCDs in B. megaterium.

Our failure to identify diploid cells among exfusants 
can be considered as indirect evidence of a limited capacity of a prokaryotic cell to accommodate additional DNA. Apparently, a duplication of $25 \%$ of the chromosome such as in a merodiploid (Schneider et al., 1982) or with additional plasmid DNA (see Young \& Hranueli, 1988) exhaust the cell's capacity for genome expression. Extra chromosomes present in exfusants are always segregated out of artificial zygotes during cell wall regeneration or upon resumption of normal growth. We believe that the cell volume or the wall-determined cell geometry may play a critical role. Particularly noteworthy are the observations of Karmazyn-Campelli et al. (1985), which reveal that complementation of parent chromosomes in an exfusant persists until cell wall regeneration is allowed to proceed. These authors have interpreted their observation in favour of chromosome silencing, which, under optimal conditions, would generate diploids from about $50 \%$ exfusants. However, we believe that they provide strong support to the idea that regeneration of the rigid cell wall of fixed size is accompanied by the restoration of the haploid state. Thus, a cell endowed with a wall of normal morphology, at least, cannot maintain diploidy during growth. Possible outcomes would be the exclusion of all except one of the chromosomes from the fused protoplast or their segregation into different regenerated cells. The latter event could account for the presence of reciprocal recombinants in exfusant colonies (Gabor \& Hotchkiss, 1983).

Finally, we would like to point out an error inherent in the common observer's intuition. Inspection of plates uniformly seeded with fewer than 100 colonies leaves the observer under the impression that a pair of cells could not possibly have been plated close enough to give rise to a single circular colony. However, observations reported here above reveal that, due to coincidence enhanced by cell sticking and surface tension, on average $0.5 \%$ of circular colonies are sectored and consist of a mixed population. This phenomenon has certainly occurred, but has not necessarily been taken into account, in previous publications involving the analyses of experiments based either on microbial colony or, to a lesser extent, on phage plaque methodology. Incidentally, rigorous methods of identification of phage mutants recommend subcloning by plating fewer than ten p.f.u. per plate (E. Kellenberger, personal communication), a precaution which, together with spreading cells in a top layer, yielding smaller colonies, could have usefully been taken in the study of exfusants.

\section{References}

Bohin, J. P., Ben Khalifa, K., Gulllen, N., Schaeffer, P. \& Hirschbein, L. (1982). Phenotypic expression in vivo and transform- ing activity in vitro: two related functions of folded bacterial chromosomes. Molecular and General Genetics 185, 65-68.

BREMER, H. \& DENNIS, P. P. (1987). Modulation of chemical composition and other parameters of the cell by growth rate. In Escherichia coli and Salmonella thyphimurium: Cellular and Molecular Biology, vol. 2, pp. 1527-1542. Edited by F. C. Neidhart, J. L. Ingraham, K. B. Low, B. Magasanik, M. Schaechter \& H. E. Umbarger. Washington, DC: American Society for Microbiology.

Budman, D. R. \& Pardee, A. B. (1967). Thymidine and thymine incorporation into deoxyribonucleic acid: inhibition and repression by uridine of thymidine phosphorylase of Escherichia coli. Journal of Bacteriology 94, 1546-1550.

BURKHOLDER, P. R. \& Giles, N. H. (1947). Induced biochemical mutations in Bacillus subtilis. American Journal of Botany 34, 345-348.

Chambers, S. P., Prior, S. E., Barstow, D. A. \& Minton, N. P. (1988). The PMTL nic ${ }^{-}$cloning vectors. I. Improved pUC polylinker region to facilitate the use of sonicated DNA for nucleotide sequencing. Gene 68, 139-149.

Del Sal, G., Manfioletti, G. \& SChneider, C. (1988). A one-tube plasmid DNA mini-preparation suitable for sequencing. Nucleic Acids Research 16, 9878.

DONACHE, W. D. (1968). Relationship between cell size and time of initiation of DNA replication. Nature, London 219, 1077-1079.

Eng, R. H. K., Padberg, F. T., Smith, S. M., TAN, E. N. \& Cherubin, C. E. (1991). Bactericidal effects of antibiotics on slowly growing and nongrowing bacteria. Antimicrobial Agents and Chemotherapy 35, 1824-1828.

FeinberG, A. P. \& Vogelstein, B. (1983). A technique for radiolabeling DNA restriction endonuclease fragments to high specific activity. Analytical Biochemistry 132, 6-13.

FERRARI, E., HENNER, D. J. \& Hoch, J. A. (1981). Isolation of Bacillus subtilis genes from a Charon 4A library. Journal of Bacteriology 146, $430-432$.

FLeISCHER, E. R. \& VARY, P. S. (1985). Genetic analysis of fusion recombinants and presence of noncomplementing diploids in Bacillus megaterium. Journal of General Microbiology 131, 919-926.

FODOR, K. \& ALFöLDI, L. (1976). Fusion of protoplasts of Bacillus megaterium. Proceedings of the National Academy of Sciences of the United States of America 73, 2147-2150.

FodOR, K., LipPaI-CsanAdY, L. \& AlFöldi, L. (1983). A search for biparentals in Bacillus megaterium. Experientia (supplementum) 45, 328-329.

GaboR, M. H. \& Hotchkiss, R. D. (1979). Parameters governing bacterial regeneration and genetic recombination after fusion of Bacillus subtilis protoplasts. Journal of Bacteriology 137, 1346-1353.

GABOR, M. H. \& HOTCHKISS, R. D. (1982). Analysis of randomly picked genetic recombinants from Bacillus subtilis protoplast fusion. In Genetic Exchange: a Celebration and a New Generation, pp. 283-292. Edited by U. N. Streips, S. H. Goodgal, W. R. Guild \& G. A. Wilson. New York: Dekker.

GABOR, M. H. \& HoTCHKISs, R. D. (1983). Reciprocal and nonreciprocal recombination in diploid clones from Bacillus subtilis protoplast fusion: association with the replication origin and terminus. Proceedings of the National Academy of Sciences of the United States of America 80, 1426-1430.

Guillen, N., SANChez-Rivas, C. \& Hirschbein, L. (1983). Absence of functional RNA encoded by a silent chromosome in non-complementing diploids obtained from protoplast fusion in Bacillus subtilis. Molecular and General Genetics 191, 81-85.

Gulllen, N., Amar, M. \& Hirschbein, L. (1985). Stabilized noncomplementing diploids $(\mathrm{Ncd})$ from fused protoplast products of $B$. subtilis. EMBO Journal 4, 1333-1338.

HotChKiss, R. D. \& GABOR, M. H. (1980). Biparental products of bacterial protoplast fusion showing unequal parental chromosome expression. Proceedings of the National Academy of Sciences of the United States of America 77, 3553-3557.

IVES, C. L. \& BoTT, K. F. (1990). Characterization of chromosomal DNA amplifications with associated tetracycline resistance in Bacillus subtilis. Journal of Bacteriology 172, 4936-4944.

KarAmatA, D. \& Gross, J. D. (1970). Isolation and genetic analysis of temperature-sensitive mutants of $B$. subtilis defective in DNA synthesis. Molecular and General Genetics 108, 277-287. 
Karmazyn-Campelli, C., Savelli, B., Rogers, H. J. \& Schaeffer, P. (1985). Inverse relationship between formation of phenotypically recombinant clones and cell wall regeneration after fusion of Bacillus subtilis protoplasts. Journal of General Microbiology 131, 1635-1638.

LEVI, C. (1978). Etude génétique et cytologique de la fusion cellulaire chez Bacillus subtilis et Escherichia coli. Thèse de $3^{\text {eme }}$ cycle, Université de Paris-sud, Centre d'Orsay.

Levi, C., Sanchez-Rivas, C. \& Schaeffer, P. (1977). Further genetic studies on the fusion of bacterial protoplasts. FEMS Microbiology Letters 2, 323-326.

LeVi-Meyrueis, C., Sanchez-Rivas, C. \& Schaeffer, P. (1980). Formation de bactéries diploïdes stables par fusion de protoplastes de Bacillus subtilis et effet de mutations rec- sur les produits de fusion formés. Comptes Rendus de l'Académie des Sciences, Paris D291, 6770

LOPEZ, F., GuILLEN, N. \& HiRsChBEIN, L. (1986). Further characterization of the inactive chromosome from Bacillus subtilis stabilized noncomplementing diploids. In Bacillus Molecular Genetics and Biotechnology Applications, pp. 73-86. Edited by A. T. Ganesan \& J. A. Hoch. New York: Academic Press.

LORENZ, M. G., AARDEMA, B. W. \& WACKeRnAGEL, W. (1988). Highly efficient genetic transformation of Bacillus subtilis attached to sand grains. Journal of General Microbiology 134, 107-112.

Maniatis, T., Fritsch, E. F. \& SAmbrooK, J. (1982). Molecular Cloning. A Laboratory Manual. Cold Spring Harbor, NY. Cold Spring Harbor Laboratory.

MARMUR, J. (1961). A procedure for the isolation of deoxyribonucleic acid from microorganisms. Journal of Molecular Biology 3, 208-218.

NiaudeT, B., Goze, A. \& EHRlich, S. D. (1982). Insertional mutagenesis in Bacillus subtilis: mechanism and use in gene cloning. Gene 19, 277-284.

NiAUDET, B., JANNIERE, L. \& EHRLICH, S. D. (1985). Integration of linear, heterologous DNA molecules into the Bacillus subtilis chromosome: mechanism and use in induction of predictable rearrangements. Journal of Bacteriology 163, 111-120.

Petit, M.-A., Joliff, G., Mesas, J. M., Klier, A., Rapoport, G. \& EHRLICH, S. D. (1990). Hypersecretion of a cellulase from Clostridium thermocellum in Bacillus subtilis by induction of chromosomal DNA amplification. Bio/technology 8, 559-563.

Romanowski, G., Lorenz, M. G. \& WaCkernagel, W. (1991). Adsorption of plasmid DNA to mineral surfaces and protection against DNaseI. Applied and Environmental Microbiology 57, 10571061.

RUTBERG, L. (1969). Mapping of a temperate bacteriophage active on Bacillus subtilis. Journal of Virology 3, 38-44.

SANCHEZ-RIVAS, C. (1982). Direct selection of complementing diploids from PEG-induced fusion of Bacillus subtilis protoplasts. Molecular and General Genetics 185, 329-333.

Sanchez-Rivas, C., LeVi-Meyrueis, C., Lazard-Monier, F. \& SCHARFFER, P. (1982). Diploid state of phenotypically recombinant progeny arising after protoplast fusion in Bacillus subtilis. Molecular and General Genetics 214, 321-324.

Schaeffer, P., Millet, J. \& AUBert, J.-P. (1965). Catabolic repression of bacterial sporulation. Proceedings of the National Academy of Sciences of the United States of America 54, 704-711.

SCHAEFFER, P., CAMI, B. \& HotChKISS, R. D. (1976). Fusion of bacterial protoplasts. Proceedings of the National Academy of Sciences of the United States of America 73, 2151-2155.

Schlaeppi, J.-M., Pooley, H. M. \& Karamata, D. (1982). Identification of cell wall subunits in Bacillus subtilis and analysis of their segregation during growth. Journal of Bacteriology 149, 329-337.

SCHNEIDER, A.-M., Gaisne, M. \& ANAGnostopoulos, C. (1982). Genetic structure and internal rearrangements of stable merodiploids from Bacillus subtilis strains carrying the trpE26 mutation. Genetics 101, 189-210.

TILBY, M. J. (1978). Detergent-resistant variants of Bacillus subtilis with reduced cell diameter. Journal of Bacteriology 136, 10-18.

TraCH, K. \& HoCH, J. A. (1989). The Bacillus subtilis spo0B stage 0 sporulation operon encodes an essential GTP-binding protein. Journal of Bacteriology 171, 1362-1371.

WYRICK, P. B. \& RoGERS, H. J. (1973). Isolation and characterization of cell wall-defective variants of Bacillus subtilis and Bacillus licheniformis. Journal of Bacteriology 116, 456-465.

YounG, M. \& HranUeli, D. (1988). Chromosomal gene amplification in Gram-positive bacteria. In Recombinant DNA and Bacterial Fermentation, pp. 157-200. Edited by J. A. Thompson. Boca Raton, FL. CRC Press.

Young, M., Mauel, C., Margot, P. \& Karamata, D. (1989). Pseudoallelic relationship between non-homologous genes concerned with biosynthesis of polyglycerol phosphate and polyribitol phosphate teichoic acids in Bacillus subtilis strains 168 and W23. Molecular Microbiology 3, 1805-1812. 